\title{
Milk: An Alternative Beverage for Hydration?
}

\section{Cássia Pegoretti, Adriane Elisabete Costa Antunes, Fúlvia de Barros Manchado-Gobatto, Caroline Dario Capitani}

Faculdade de Ciências Aplicadas da Unicamp, Rua Pedro Zaccaria, Limeira, Brazil

Email: cassia.pegoretti@yahoo.com.br

Received 19 February 2015; accepted 14 April 2015; published 16 April 2015

Copyright (C) 2015 by authors and Scientific Research Publishing Inc.

This work is licensed under the Creative Commons Attribution International License (CC BY). http://creativecommons.org/licenses/by/4.0/

(c) (i) Open Access

\section{Abstract}

The hydration status of a physically active individual or athlete can influence his/her physical or mental performance. The degree of hypohydration may lead to serious health problems, and consequently to impair athletic performance. The consumption of water or carbohydrate-electrolyte beverages before, during and after exercise is essential to maintain fluid balance and prevent dehydration. Besides these drinks, research findings have pointed using bovine milk as an alternative to sports drinks to optimize hydration levels in athletes and physically active individuals. The nutritional composition of cow's milk promotes post-exercise rehydration process, due to the natural presence of water and electrolytes such as sodium and potassium. Although most studies have confirmed that bovine milk is a viable alternative for rehydration, recent studies have not reported significant differences between milk and some sports drinks for hydration process. Thus, milk consumption could be used as an alternative beverage for the hydration process.

\section{Keywords}

Milk, Milk Proteins, Athletic Performance, Fluid Therapy, Dehydration

\section{Introduction}

Physical activity results in loss of body water and electrolytes through sweating, which are essentials for regulating body temperature. The loss of $2 \%$ of body mass during exercise can cause a decrease in performance and can also compromise aerobic, cognitive and mental performance [1]. Therefore, adequate fluid intake during exercise is highly recommended. According to the American College of Sports Medicine (2007) [2], pre-exercise hydration ensures euhydration and water balance, in order to subsequently ensure the goal to replace fluid and electrolyte looses. Thus, the consumption of carbohydrate-electrolyte beverages (sports drinks), especially dur- 
ing exercise, is better than water consumption to ensure the replacement of fluids and electrolytes [2].

An alternative to available commercial sports drink is cow's milk or drinks containing cow's milk proteins, especially whey proteins, which has shown positive results in the post-exercise rehydration process, according to some referenced studies [3]-[8]. These studies associate the hydration benefits with nutritional aspects of milk, namely natural electrolytes composition (sodium and potassium), presence of water, carbohydrates and proteins and longer gastric emptying time [3]-[8].

As an alternative strategy to improve hydration during sporting activities, the aim of this work was to conduct a literature review about the use of milk as an option to replace the lost fluids during exercises.

Thus, a qualitative systematic review was conducted in international databases (PubMed, Science Direct, Scielo) between August and October 2014 using the keywords: hydration, dehydration, fluid replacement, bovine milk, milk proteins, athletic performance, and exercises, in order to synthesize qualitative evidence to address aspects other than effectiveness on sports beverage to hydration. The inclusion criteria considered articles published between 2006 and 2014.

\section{Bovine Milk Composition and Characteristics}

Bovine milk is a key dietary protein source in human diets. Its composition has high amounts of essential amino acids (504 mg.g of crude protein ${ }^{-1}$ ), which is an important nutrient source for the human body, especially for lacto-vegetarian diets [9] [10]. Milk proteins can be fractionated into two major groups, which means that in acidification at $\mathrm{pH} 4.6$, one group, about $80 \%$ of total proteins found in milk, are precipitated from the solution and this fraction is referred as casein [11]. The other group is composed by the whey proteins (20\% of total proteins). Whey proteins come from the proteins that remain soluble under these conditions [12]. When evaluated separately, whey proteins have a protein efficiency ratio (PER) of 3.0 - 3.2, while the caseins have PER of 2.5, demonstrating the superior quality of whey proteins [11] [13]. Casein has higher content of histidine, methionine, phenylalanine and other non-essential amino acids such as arginine, glutamine, proline, serine and tyrosine [14]. Whey proteins have a larger amount of branched-chain amino acids (BCAA) leucine, isoleucine and valine [14]. Due to the bovine milk amino acids attributes, it is widely used in sports nutrition to help performance enhancement, muscle recovery after exercise and muscle mass gain in physically active individuals and athletes [9]. Whole bovine milk has $95 \%$ of triacylglycerol, $2 \%$ of diacylglycerol, less than $0.5 \%$ of cholesterol, about $1 \%$ of phospholipids and $0.5 \%$ of free fatty acids less. The origin of the animal, stage of lactation, mastitis, ruminal fermentation are factors that influence the quantity and milk fat composition [15].

Another important milk's property regards its source of calcium $\left(122 \mathrm{mg} \cdot 100 \mathrm{~g}^{-1}\right)$, phosphate $\left(119 \mathrm{mg} \cdot 100 \mathrm{~g}^{-1}\right)$ and vitamins such as riboflavin $\left(163 \mu \mathrm{g} \cdot 100 \mathrm{~mL}^{-1}\right)$, relatively rich in thiamine $\left(40 \mu \mathrm{g} \cdot 100 \mathrm{~mL}^{-1}\right)$, cobalamin $(0.42$ $\left.\mu \mathrm{g} \cdot 100 \mathrm{~mL}^{-1}\right)$ and vitamins $\mathrm{A}\left(27-60 \mu \mathrm{g} \cdot 100 \mathrm{~mL}^{-1}\right)$ and $\mathrm{D}\left(0.1-1.4 \mu \mathrm{g} \cdot 100 \mathrm{~mL}^{-1}\right)$, the latter two liposoluble vitamins which are lost in the skimming process [11] [15] [16].

Approximately $70 \%$ of dietary calcium intake comes from milk and its derivatives, making its adequate intake extremely important to maintain healthy bones and teeth [9]. Calcium also has an important effect on muscle contraction, as it is the mineral responsible for releasing the active actin and myosin sites, forming the crossbridge. During exercise there is sarcoplasmic reticulum calcium depletion, and if not reversed, there may be mineral deficiency for muscle contraction [17]. Thus, calcium intake after exercise is necessary to replace lost reserves during physical activity and also to promote athlete's good bone health [18]. Whole milk is also a vitamin D source. Vitamin D is responsible for calcium homeostasis, therefore has an important role in bone mineralization. It is also responsible for the increased calcium uptake in muscle cells, promoting greater availability of this mineral for muscle contraction [19].

The main nutritional bovine milk characteristics is related to a possible post-exercise hydration improvement, because of its consistency of natural water presence, besides having sodium and potassium, which are essential in the homeostasis of body fluids [20]. Milk contains sodium and potassium, important electrolytes in the hydration process. About $250 \mathrm{~mL}$ of whole and skim milk contains, respectively, 126 to $133 \mathrm{mg}$ of $\mathrm{Na}^{+}$and 391 to $431 \mathrm{mg}$ of $\mathrm{K}^{+}$[21]. In a dehydration condition, sodium intake is important because it increases plasma volume, stimulates voluntary thirst and glucose absorption in the small intestine [4] and for that reason carbohydratebased drinks contain added sodium [4]. In 1997, Maughan, Leiper and Shirreffs reported that better hydrating drinks should contain at least $50 \mathrm{mmol} / \mathrm{L}$ of sodium [22]. However, in 2007, Shirreffs et al. [4] observed that skim milk with added sodium (58 mmol/L sodium) was not different in hydration when compared with skim 
milk (38.6 mmol/L sodium). Besides, both drinks were more efficiently in the hydration process comparing to water $(0.3 \mathrm{mmol} / \mathrm{L}$ sodium) and carbohydrate beverages ( $23 \mathrm{mmol} / \mathrm{L}$ sodium). Skim milk with sodium increased the sodium concentration in the urine [4]. Thus, natural sodium concentration in milk (35 mmol/L sodium), seems to be sufficient to improve hydration process [4] [23], maintain the plasma osmolality and prevents the production of dilute urine [8] [20].

The potassium function in hydration is already unknown; however it is the main intracellular cation involved in restoring the fluid balance, due to water retention in the intracellular space [20]. Supplying an individual proper hydration, besides restoring the electrolytes, as well, a complete hydration requires bringing through the fluids lost [24]. In this sense, the composition of milk favors this process, because in addition to sodium and potassium concentration, it contains approximately $80 \%$ of water.

Other factors that influence hydration process consider the gastric emptying time and intestinal absorption in relation to serum osmolality [25]. The amount of liquid ingested, as well as its composition and nutritional energy density affects these parameters and consequently the hydration [25]. Thus, the higher is energy value of a drink, the lower is gastric emptying time and intestinal absorption, resulting in the control of serum osmolality, preventing excessive urinary excretion and ensuring the hydration process [26].

The milk energy ability varies from $90 \mathrm{kcal} \cdot 250 \mathrm{~mL}^{-1}$ (skim milk) to $159 \mathrm{kcal} \cdot 250 \mathrm{~mL}^{-1}$ (whole milk), while sports drinks have between 52 and $85 \mathrm{kcal} \cdot 250 \mathrm{~mL}^{-1}$ [21]. This difference is due to the fact that milk has protein and fats that sports drinks do not have [21]. Thus, milk composition may act in gastric emptying and hydration improvement [20]. Relationship between milk proteins ingestion and the gastric emptying time was identified in 1997 by Calbet \& MacLean [26]. Four drinks were assessed in equal volumes $(600 \mathrm{~mL})$; containing glucose $(0.1$ $\left.\mathrm{kcal} \cdot \mathrm{mL}^{-1}\right)$; pea protein hydrolysate $\left(0.2 \mathrm{kcal} \cdot \mathrm{mL}^{-1}\right)$; hydrolyzed whey protein $\left(0.2 \mathrm{kcal} \cdot \mathrm{mL}^{-1}\right)$; and milk protein $\left(0.7 \mathrm{kcal} \cdot \mathrm{mL}^{-1}\right)$. They observed difference $(\mathrm{p}<0.05)$ between the gastric emptying time with milk proteins $(26.4$ $\pm 10 \mathrm{~min}$ ) compared to the solution containing glucose $(9.4 \pm 1.2 \mathrm{~min})$ [26]. The amount of liquid ingested and its nutritional composition and energy density could affect these parameters and consequently hydration [25]. Thus, the higher drink energy content the lower gastric emptying time and intestinal absorption, which mean result in serum osmolality controlling to prevent excessive urinary excretion and ensuring the hydration process [26].

In a hydration process, the amount of carbohydrate must be taken into account and its effects must be evaluated. The Institute of Medicine (1994) [27] published in Fluid Replacement Guides that the amount of carbohydrates in hydrating drinks should be between $5 \%-10 \%$, which is a ratio found naturally in milk and used in commercial sports drinks $(6.0 \%-6.4 \%)$ [21]. When analyzing fat proportion in milk, there are three products: whole, semi skim and skim milk, it ranges from $4.8 \%$ to $5.2 \%$ [21] [28].

The addition of carbohydrates (from $40 \mathrm{~g}$ ) in drinks could also increase energy and decrease gastric emptying time, as observed by Vist and Maughan [29] in comparison to water. A hypertonic drink (10\% carbohydrate) resulted in shorter gastric emptying time, and allows reduced urine production, increased water retention, and smaller plasma volume when compared to a hypotonic drink (2\% carbohydrate) [30]. Lee et al. (2008) [31] observed a greater feeling of fullness after consuming milk when compared to other drinks analyzed. The same result was found in the study of Watson et al. (2008) when milk for hydration was analyzed [5]. The ratio of milk proteins is 4:1 (casein:whey protein), which perks a shorter gastric emptying time, favoring a decrease in diuresis [5] [6] [21].

In this context, the sports drinks and milk composition could be better to promote hydration process in relation to water. However, the association between milk consumption and longer gastric emptying time has been questioned in the last years. When $250 \mathrm{~mL}$ of black tea added with $50 \mathrm{~mL}$ of whole milk, was evaluated in preoperative people evinced there was no differences in gastric emptying time when is compared with consumption of just black tea $300 \mathrm{~mL}$ [32]. In 2013, a study with rats evaluated the effect on hydration by the consumption of water (W); whole milk (WM); sports drinks (SD); milk protein solution (MPS) and milk electrolyte solution (MES) [33]. The analysis of the hydration pattern showed a significant difference about $55 \%$ less urine produced in the WM group compared to the $\mathrm{W}$ group. The plasma aldosterone levels increased significantly in the MPS and WM groups compared with $\mathrm{W}$, and the plasma osmolality level was higher in the MPS group compared with $\mathrm{W}$ and MES, but there was no difference in gastric emptying time (SD = $50 \mathrm{~min}$; MPS = 52 min; $\mathrm{W}=54 \mathrm{~min}$; $\mathrm{WM}=62 \mathrm{~min}$ ). Moreover, milk proteins promoted greater water retention and high plasma aldosterone levels, suppressing plasma osmolality decrease, but without changing on gastric emptying time [33]. 


\section{Bovine Milk Consumption, Exercise and Hydration Status}

Shireffs, Watson and Maughan (2007) [4] compared skim milk, skim milk with NaCl added, water and isotonic drink - in equal volumes (150\% of body weight loss) - in hydration of physically active subjects. The intake of water and a carbohydrate drink, compared to the consumption of milk and milk with $\mathrm{NaCl}$, seemed to increase urine production during the recovery period, and showed milk as an effective solution to promote hydration in comparison to the same volume of water or sports drink in post-exercise [4].

In 2008, the same group of researchers compared skim milk to a commercial drink with carbohydrates and electrolytes in post-exercise, observing lower production of urine and positive fluid balance until ending the rest period for the individuals who consumed skim milk [5]. However, there were no significant differences about consumption of skim milk and commercial drink in the ability to perform exercise after 3 hours resting [5].

A study with 38 children was conducted in order to ascertain whether there was better hydration with consumption of skim milk (SM) in relation to water and hydrating sports drink (CES) [8]. There was greater water retention with the consumption of SM, and the fluid balance was negative during the recovery period for SM group. Although the results achieved show better hydration with SM, the volume ingested must be considered since the study only presented $100 \%$ loss of body weight and ideally a larger volume should be preferred $150 \%$ [8].

More recently, the effect of consumption of different drinks: bovine milk, soy milk, liquid meal supplement milk-based (Sustagen Sport-Nestlé ${ }^{\circledR}$ ) and a sport drink (Powerade-Coca-Cola ${ }^{\circledR}$ ) on hydration status was evaluated in the post exercise period. This study showed that a better hydration was promoted by the beverage containing milk-based drinks (Sustagen Sport-Nestlé ${ }^{\circledR}$ ). The authors stated that the additional energy supply and the amount of sodium in the milk-based drinks influenced the recovery of lost fluids after the exercise [34].

In summary, it was observed that drink's composition directly interfere in the rehydration process and skim milk is a suitable alternative to provide hydration. It should be highlighted that in order to promote body fluid homeostasis, the total volume of liquid ingested should be greater than the lost volume in the exercise (corresponding to $150 \%$ of body mass loss) [35]. However, some studies have demonstrated that the consumption of liquid ad libitum, taking in account thirst sensation seems to be enough to promote proper hydration status [36]-[38]. Thus, studies investigation consumption of different volumes of milk, and comparison with other beverages, should be conducted in order to understand the milk’s role in hydration process.

In the Table 1 are shown a summary of studies that used milk or others beverages for promote post-exercise

Table 1. Current studies on milk and its proteins added in drinks for hydration.

\begin{tabular}{|c|c|c|c|}
\hline References & Subjects/supplementation & Parameters analyzed & Main results \\
\hline \multirow{5}{*}{$\begin{array}{l}\text { Shirreffs, Watson, } \\
\text { Maughan, } 2007 \\
{[4]}\end{array}$} & \multirow{5}{*}{$\begin{array}{l}5 \text { man } \\
6 \text { woman } \\
\text { PA } \\
\text { Recovery time: } 4 \text { h } \\
\text { Supple.: } 20 \text { min after exercise } \\
\text { every } 15 \text { min to complete } 1 \mathrm{~h} \\
\text { W; W + Na; CE; Water } \\
\text { Vol.:150\% BML }\end{array}$} & Vol. of urine excreted & $\begin{array}{l}\mathrm{W}: 611 \pm 207 \mathrm{~mL}^{*} \\
\mathrm{~W}+\mathrm{Na}: 550 \pm 141 \mathrm{~mL}^{*} \\
\mathrm{CE}: 1184 \pm 321 \mathrm{~mL} \\
\text { Water: } 1205 \pm 142 \mathrm{~mL}\end{array}$ \\
\hline & & \% liquid retained & $\begin{array}{l}\text { W: } 69 \% \pm 10 \%{ }^{*} \\
\text { W + Na: } 72 \% \pm 4 \%{ }^{*} \\
\text { CE: } 38 \% \pm 16 \% \\
\text { Water: } 36 \% \pm 10 \%\end{array}$ \\
\hline & & Electrolyte excretion in urine & $\begin{array}{l}\text { Greater amount of electrolytes excreted } \\
\text { with the consumption of } \mathrm{W}+\mathrm{Na}^{*}\end{array}$ \\
\hline & & Urine osmolality (mOsmol/kg) & $\begin{array}{l}1 \mathrm{~h} \text { after supple.: } \\
\text { W: } 509 \pm 250^{*} \\
\mathrm{~W}+\mathrm{Na}: 636 \pm 296^{*} \\
\mathrm{CE}: 92 \pm 49 \\
\text { Water: } 92 \pm 49 \\
2 \text { h after supple.: } \\
\text { W: } 607 \pm 223^{*} \\
\text { W }+\mathrm{Na}: 686 \pm 179^{*} \\
\mathrm{CE}: 129 \pm 64 \\
\text { Water: } 149 \pm 75\end{array}$ \\
\hline & & Subjective sensations & $\begin{array}{l}\text { Feeling of hunger with the consumption of } \\
\text { water and CE: sweeter drink }\end{array}$ \\
\hline
\end{tabular}




\section{Continued}

\begin{tabular}{|c|c|c|c|}
\hline & & Water balance & $\begin{array}{l}\text { W: } 10 \pm 190 \mathrm{~mL}^{*} \\
\mathrm{~W}+\mathrm{Na}: 60 \pm 80 \mathrm{~mL}^{*} \\
\mathrm{CE}:-50 \pm 230 \mathrm{~mL} \\
\text { Water: }-20 \pm 150 \mathrm{~mL}\end{array}$ \\
\hline \multirow{9}{*}{$\begin{array}{l}\text { Watson et al. } 2008 \\
\text { [5] }\end{array}$} & $\begin{array}{l}7 \text { man } \\
\text { PA }\end{array}$ & Vol. of urine excreted & $\begin{array}{l}2 \mathrm{~h} \text { after supple.: } \\
\text { SM: } 400 \pm 84 \mathrm{~mL}^{*} \\
\text { CE: } 679 \pm 297 \mathrm{~mL}\end{array}$ \\
\hline & \multirow{8}{*}{$\begin{array}{l}\text { Recovery time: } 3 \mathrm{~h} \\
\text { Supple.: } 30 \text { min after exercise } \\
\text { every } 15 \text { min to complete } 1 \mathrm{~h} \\
\text { SM and CE } \\
\text { Vol.:150\% BML }\end{array}$} & $\%$ retained liquid & $\begin{array}{l}\text { SM: } 77 \% \pm 6 \%^{*} \\
\text { CE: } 62 \% \pm 17 \%\end{array}$ \\
\hline & & Water balance & $\begin{array}{l}\text { SM: } 191 \pm 162 \mathrm{~mL}^{\mathrm{a}} \\
\text { CE: }-135 \pm 392 \mathrm{~mL}\end{array}$ \\
\hline & & Electrolyte excretion in urine & SM: $\uparrow^{*}$ \\
\hline & & Serum osmolality (mOsmol/kg) & SM: $\uparrow$ until the end of recovery \\
\hline & & Serum electrolytes & SM: $\uparrow$ potassium $^{\mathrm{b}}$ \\
\hline & & Plasma volume (mL) & No differences \\
\hline & & Blood glucose (mmol/L) & $\begin{array}{l}\text { Immediately after supplement: } \\
\text { SM: } 4.97 \pm 0.46^{* *} \\
\text { CE: } 7.91 \pm 1.30 \\
2 \text { h after supplement.: } \\
\text { CE: } \downarrow^{c}\end{array}$ \\
\hline & & Subjective sensations & $\begin{array}{l}\text { CE: sweeter drink }{ }^{\mathrm{d}} \\
\text { Feeling of hunger with water consumption } \\
\text { Gastric fullness: } \uparrow \mathrm{SM}^{\mathrm{f}}\end{array}$ \\
\hline
\end{tabular}

38 children

Recovery time: $2 \mathrm{~h}$

Volterman et al., $\quad$ Supple: $0 \mathrm{~min}, 15 \mathrm{~min}$ and 30

2014 [8] min after exercise

Vol. of urine excreted $\quad$ Water $>\mathrm{CES}>\mathrm{SM}^{* *}$

Water; CES; SM

Vol.:100\% BML

Water: $47 \% \pm 26 \%$

$\%$ retained liquid

CES: $59 \% \pm 20 \%$

SM: $74 \% \pm 18 \%{ }^{* *}$

Water balance

Negative for all drinks, but less negative for SM in relation to water**

Urine density $(\mathrm{g} / \mathrm{mL})$

No significant difference

Subjective responses

CES more pleasant than SM and water ${ }^{* *}$ Greater preference for $\mathrm{CES}^{\mathrm{g}}$

15 man

Recovery time: $4 \mathrm{~h}$

Supple.: $30 \mathrm{~min}$ after exercise

Desbrow et al., $\quad$ every 15 min to complete $1 \mathrm{~h}$

2014 [34]

Cow's milk, soy milk,

Sustagen Sport-Nestlé ${ }^{\circledR}$,

Powerade-Coca-Cola ${ }^{\circledR}$

Vol.: 150\% BML

\begin{tabular}{|c|c|}
\hline Water balance & 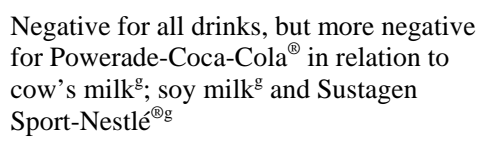 \\
\hline Vol. of urine excreted & 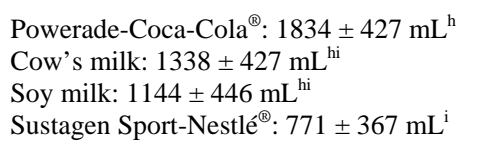 \\
\hline$\%$ retained liquid & $\begin{array}{l}\text { Powerade-Coca-Cola }{ }^{\circledR}: 16.6 \% \pm 16.5 \%{ }^{\mathrm{h}} \\
\text { Cow’s milk: } 40 \% \pm 24.9 \%{ }^{\mathrm{hi}} \\
\text { Soy milk: } 46.9 \% \pm 19.9 \%{ }^{\mathrm{hi}} \\
\text { Sustagen Sport-Nestle }^{\circledR \mathrm{B}}: 65.1 \% \pm 14.7 \%^{\mathrm{i}}\end{array}$ \\
\hline Subjective responses & $\begin{array}{l}\text { Sustagem sweeter than the cow's milk and } \\
\text { soy milk }^{*}\end{array}$ \\
\hline
\end{tabular}

PA, physically active; Supple., supplementation; Vol., volume; BML, body mass loss; $\mathrm{W}$, milk $0.2 \%$ fat; $\mathrm{W}+\mathrm{Na}$, milk $0.2 \%$ fat $+20 \mathrm{mmol} / \mathrm{NaCl}$; CE, commercial carbohydrate-electrolyte drink; SM, skim milk; CES, 8 g carbohydrate $+9.9 \mathrm{mmol} / \mathrm{L}$ sodium $+3.8 \mathrm{mmol} / \mathrm{L}$ potassium; ${ }^{*}$ Significant difference $P<0.05 .{ }^{* *}$ Significant difference $P=0.001$. ${ }^{\mathrm{a}}$ Significant difference between the pre-exercise values $P<0.05$. ${ }^{\mathrm{b}}$ Significant difference $P=0.030$. ${ }^{\mathrm{c}}$ Significant difference $P=0.044$. ${ }^{\mathrm{d}}$ Significant difference $P=0.007$. ${ }^{\mathrm{e}}$ Significant difference $P=0.010$. ${ }^{\mathrm{f}}$ Significant difference $P=0.033$. ${ }^{\mathrm{g}}$ Significant difference $P<0.01$. ${ }^{\mathrm{h}}$ Mean statisitically significantly different from Sustagen Sport. ${ }^{\mathrm{i}}$ Mean statistically significantly different from Powerade. 
hydration. These studies suggested that the use of milk in the post exercise can help to replace fluids and promote the hydration. Despite the benefits regarding the intake of milk in post-exercise, it should be pointed out that some individuals have hypolactasia/alactasia, allergy to milk proteins or some other intolerance that prevents its consumption. In this case, are recommended to ingest alternative drinks rather than milk-based drinks to restore the normal physiological hydration state in the post-exercise [4]. For individuals with hypolactasia diagnosis, may be prescribed the lactose-free milk [39] as an alternative. Lactose-free milk was described as good recovery drink when compared to water and sports drink [40]. However, there are no studies that compared the effects of this type of milk on post-exercise hydration.

\section{Final Remarks}

Bovine low-fat milk seems to be an alternative beverage for physically active individuals and athletes who experienced fluid loss during exercise. However, there are conflicting results regarding the effect of milk on hydration status; therefore, more studies are needed to understand the real effect of milk on hydration process.

\section{Conflict of Interest}

None.

\section{References}

[1] Kenefick, R.W. and Cheuvront, S.N. (2012) Hydration for Recreational Sport and Physical Activity. Nutrition Reviews, 70, S137-S142. http://dx.doi.org/10.1111/j.1753-4887.2012.00523.x

[2] Sawka, W.N., Burke, L.W., Eichner, E.R., et al. (2007) Position Stand: Exercise and Fluid Replacement. Medicine and Science in Sports and Exercise, 39, 377-390. http://dx.doi.org/10.1249/mss.0b013e31802ca597

[3] Seifert, J., Harmon, J. and DeClercq, P. (2006) Protein Added to a Sports Drink Improves Fluid Retention. International Journal of Sport Nutrition and Exercise Metabolism, 16, 420-429.

[4] Shirreffs, S.W., Watson, P. and Maughan, R.J. (2007) Milk as an Effective Post-Exercise Rehydration Drink. The British Journal of Nutrition, 98, 173-180. http://dx.doi.org/10.1017/S0007114507695543

[5] Watson, P., Love, T.D., Maughan, R.J., et al. (2008) A Comparison of the Effects of Milk and a Carbohydrate-Electrolyte Drink on the Restoration of Fluid Balance and Exercise Capacity in a Hot, Humid Environment. European Journal of Applied Physiology, 104, 633-642. http://dx.doi.org/10.1007/s00421-008-0809-4

[6] James, L.J., Clayton, D.J. and Evans, G.W. (2011) Effect of Milk Protein Addition to a Carbohydrate-Electrolyte Rehydration Solution Ingested after Exercise in the Heat. The British Journal of Nutrition, 105, 393-399. http://dx.doi.org/10.1017/S0007114510003545

[7] James, L.J., Evans, G.W., Madin, J., et al. (2013) Effect of Varying the Concentrations of Carbohydrate and Milk Protein in Rehydration Solutions Ingested after Exercise in the Heat. The British Journal of Nutrition, 110, 1285-1291. http://dx.doi.org/10.1017/S0007114513000536

[8] Volterman, K.A., Obeid, J., Wilk, B., et al. (2014) Effect of Milk Consumption on Rehydration in Youth Following Exercise in the Heat. Applied Physiology, Nutrition, and Metabolism, 39, 1-8. http://dx.doi.org/10.1139/apnm-2014-0047

[9] Cominetti, C., Bortoli, W.C. and Cozzolino, S.W.F. (2009) Leite: Fonte de proteínas, minerais e vitaminas. In: Antunes, A.E.C. and Pacheco, W.T.B., Eds., Leite para adultos: Mitos e fatos frente à ciência, Varela, São Paulo, 177-213.

[10] Food and Agriculture Organization/World Health Organization (1991) Protein Quality Evaluation. Joint FAO/WHO Expert Consultation. FAO Food and Nutrition Paper 51. FAO, Roma.

[11] Penna, A.L.B., Almeida, K.E. and Oliveira, W.N. (2009) Soro de leite: Importância biológica, comercial e industrialPrincipais produtos. In: Oliveira, W.N., Ed., Tecnologia de Produtos Lácteos Funcionais, Atheneu, São Paulo, 251276.

[12] McGregor, R.A. and Poppitt, S.D. (2013) Milk Protein for Improved Metabolic Health: A Review of the Evidence. Nutrition \& Metabolism, 10, 46. http://dx.doi.org/10.1186/1743-7075-10-46

[13] Antunes, A.J. (2003) Funcionalidade de Proteínas do Soro de Leite Bovino. Manole, São Paulo, 135.

[14] Hall, W.L., Millward, D.J., Long, S.J. and Morgan, L.M. (2003) Casein and Whey Exert Different Effects on Plasma Amino Acid Profiles, Gastrointestinal Hormone Secretion and Appetite. The British Journal of Nutrition, 89, 239-248. http://dx.doi.org/10.1079/BJN2002760

[15] Pereira, P.C. (2014) Milk Nutritional Composition and Its Role in Human Health. Nutrition, 30, 619-627. 
http://dx.doi.org/10.1016/j.nut.2013.10.011

[16] Penna, A.L.B. (2009) O leite: Importância biológica, industrial e comercial. Fisiologia da produção de leite—Composição, propriedades físico-químicas, análises. In: Oliveira, W.N., Ed., Tecnologia de Produtos Lácteos Funcionais, Atheneu, São Paulo, 21-84.

[17] Berchtold, M.W., Brinkmeier, H. and Müntener, M. (2000) Calcium Ion in Skeletal Muscle: Its Crucial Role for Muscle Function, Plasticity, and Disease. Physiological Reviews, 80, 1215-1265.

[18] Gaffney-Stomberg, E., Lutz, L.J., Rood, J.C., Cable, S.J., Pasiakos, S.M., Young, A.J. and McClung, J.P. (2014) Calcium and Vitamin D Supplementation Maintains Parathyroid Hormone and Improves Bone Density during Initial Military Training: A Randomized, Double-Blind, Placebo Controlled Trial. Bone, 68, 46-56.

http://dx.doi.org/10.1016/j.bone.2014.08.002

[19] Rizzoli, R., Stevenson, J.C., Bauer, J.M., van Loon, L.J.C., Walrand, S., Kanis, J.A., et al. (2014) The Role of Dietary Protein and Vitamin D in Maintaining Musculoskeletal Health in Postmenopausal Women: A Consensus Statement from the European Society for Clinical and Economic Aspects of Osteoporosis and Osteoarthritis (ESCEO). Maturitas, 79, 122-132. http://dx.doi.org/10.1016/j.maturitas.2014.07.005

[20] James, L. (2013) Milk Protein and the Restoration of Fluid Balance after Exercise. In: Lamprecht, W., Ed., Acute Topics in Sport Nutrition, Karger, Basel, 120-126.

[21] Roy, B.D. (2008) Milk: The New Sports Drink? A Review. Journal of the International Society of Sports Nutrition, 5, 15. http://dx.doi.org/10.1186/1550-2783-5-15

[22] Maughan, R.J., Leiper, J.B. and Shirreffs, S.M. (1997) Factors Influencing the Restoration of Fluid and Electrolyte Balance after Exercise in the Heat. British Journal of Sports Medicine, 31, 175-182. http://dx.doi.org/10.1136/bjsm.31.3.175

[23] Vrijens, D.W. and Rehrer, N.J. (1999) Sodium-Free Fluid Ingestion Decreases Plasma Sodium during Exercise in the Heat. Journal of Applied Physiology, 86, 1847-1851.

[24] Shirreffs, S.W., Armstrong, L.E. and Cheuvront, S.N. (2004) Fluid and Electrolyte Needs for Preparation and Recovery from Training and Competition. Journal of Sports Sciences, 22, 57-63. http://dx.doi.org/10.1080/0264041031000140572

[25] Evans, G.W., Shirreffs, S.W. and Maughan, R.J. (2011) The Effects of Repeated Ingestion of High and Low Glucose-Electrolyte Solutions on Gastric Emptying and Blood ${ }^{2} \mathrm{H}_{2} \mathrm{O}$ Concentration after an Overnight Fast. The British Journal of Nutrition, 106, 1732-1739. http://dx.doi.org/10.1017/S0007114511002169

[26] Calbet, J.A.L. and MacLean, D.A. (1997) Role of Calorie Content on Gastric Emptying in Humans. The Journal of Physiology, 498, 553-559. http://dx.doi.org/10.1113/jphysiol.1997.sp021881

[27] Institute of Medicine (1994) Fluid Replacement and Heat Stress.

[28] Haug, A., Hostmark, A.T. and Harstad, O.M. (2007) Bovine Milk in Human Nutrition-A Review. Lipids in Health and Disease, 6, 25. http://dx.doi.org/10.1186/1476-511X-6-25

[29] Vist, G.E. and Maughan, R.J. (1994) Gastric Emptying of Ingested Solutions in Man: Effect of Beverage Glucose Concentration. Medicine and Science in Sports and Exercise, 26, 1269-1273. http://dx.doi.org/10.1249/00005768-199410000-00014

[30] Clayton, D.J., Evans, G.W. and James, L.J. (2014) Effect of Drink Carbohydrate Content on Postexercise Gastric Emptying, Rehydration, and the Calculation of Net Fluid Balance. International Journal of Sport Nutrition and Exercise Metabolism, 24, 79-89. http://dx.doi.org/10.1123/ijsnem.2013-0024

[31] Lee, J.K.W., Maughan, R.J., Shirreffs, S.W. and Watson, P. (2008) Effects of Milk Ingestion on Prolonged Exercise Capacity in Young, Healthy Men. Nutrition, 24, 340-347. http://dx.doi.org/10.1016/j.nut.2008.01.001

[32] Hillyard, S., Cowman, S., Ramasundaram, R., Seed, P.T. and O’Sullivan, G. (2014) Does Adding Milk to Tea Delay Gastric Emptying? British Journal of Anaesthesia, 112, 66-71. http://dx.doi.org/10.1093/bja/aet261

[33] Ishihara, K., Kato, Y., Usami, A., Yamada, M., Yamamura, A., Fushiki, T. and Seyama, Y. (2013) Electrolyte-Free Milk Protein Solution Influences Sodium and Fluid Retention in Rats. Journal of Nutritional Science, 2, 1-7. http://dx.doi.org/10.1017/jns.2012.24

[34] Desbrow, B., Jansen, S., Barrett, A., Leveritt, M.D. and Irwin, C. (2014) Comparing the Rehydration Potential of Different Milk-Based Drinks to a Carbohydrate-Electrolyte Beverage. Applied Physiology, Nutrition, and Metabolism, 39, 1366-1372. http://dx.doi.org/10.1139/apnm-2014-0174

[35] Sawka, M.N., Burke, L.M., Eichner, E.R., Maughan, R.J., Montain, S.J. and Stachenfeld, N.S. (2007) American College of Sports Medicine Position Stand: Exercise and Fluid Replacement. Medicine and Science in Sports and Exercise, 39, 377-390. http://dx.doi.org/10.1249/mss.0b013e31802ca597

[36] Noakes, T.D. (2003) Position Statement: Fluid Replacement during Marathon Running. Clinical Journal of Sport 
Medicine, 13, 309-318. http://dx.doi.org/10.1097/00042752-200309000-00007

[37] Noakes, T.D. (2010) Is Drinking to Thirst Optimum? Annals of Nutrition \& Metabolism, 57, 9-17. http://dx.doi.org/10.1159/000322697

[38] Nolte, H.W., Noakes, T.D. and Nolte, K. (2013) Ad Libitum vs. Restricted Fluid Replacement on Hydration and Performance of Military Tasks. Aviation, Space and Environmental Medicine, 84, 97-103. http://dx.doi.org/10.3357/ASEM.3378.2013

[39] Antunes, A.E.C. and Olej, B. (2009) Intolerância e sensibilidade aos componentes do leite. In: Antunes, A.E.C. and Pacheco, W.T.B., Eds., Leite para Adultos: Mitos e Fatos Frente à Ciência, Varela, São Paulo, 19-42.

[40] Sudsa-ard, K., Kijboonchoo, K., Chavasit, V., Chaunchaiyakul, R., Nio, A.Q.X. and Lee, J.K.W. (2014) Lactose-Free Milk Prolonged Endurance Capacity in Lactose Intolerant Asian Males. Journal of the International Society of Sports Nutrition, 11, 49. http://dx.doi.org/10.1186/s12970-014-0049-4 